\title{
Retraction Note: Clinical efficacy of posterior versus anterior instrumentation for the treatment of spinal tuberculosis in adults: a meta-analysis
}

Pinglin Yang, Xijing He*, Haopeng Li, Quanjin Zang and Baohui Yang

\section{Retraction}

The Publisher and Editor regretfully retract this article [1] because the peer-review process was inappropriately influenced and compromised. As a result, the scientific integrity of the article cannot be guaranteed. A systematic and detailed investigation suggests that a third party was involved in supplying fabricated details of potential peer reviewers for a large number of manuscripts submitted to different journals. In accordance with recommendations from COPE we have retracted all affected published articles, including this one. It was not possible to determine beyond doubt that the authors of this particular article were aware of any third party attempts to manipulate peer review of their manuscript.

Received: 4 March 2015 Accepted: 4 March 2015

Published online: 26 March 2015

\section{Reference}

1. Yang P, He X, Haopeng L, Zang Q, Yang B. Clinical efficacy of posterior versus anterior instrumentation for the treatment of spinal tuberculosis in adults: a meta-analysis. J Orthop Surg Res. 2014;9:10.

\footnotetext{
*Correspondence: xijing_h@vip.tom.com

Second Department of Orthopedics, Second Affiliated Hospital of Xi'an Jiaotong University Medical School, No.157, West Fifth Road, Xi'an, Shaanxi
}

Submit your next manuscript to BioMed Central and take full advantage of:

- Convenient online submission

- Thorough peer review

- No space constraints or color figure charges

- Immediate publication on acceptance

- Inclusion in PubMed, CAS, Scopus and Google Scholar

- Research which is freely available for redistribution

Submit your manuscript at

www.biomedcentral.com/submit

\section{() Biomed Central}

